\title{
FLUNARIZINE AND CINNARIZINE-INDUCED PARKINSONISM: 25 YEARS OF DE MELO-SOUZA'S SYNDROME
}

Drug-induced Parkinsonism (DIP) is the second most common cause of parkinsonism (PK)'. Flunarizine and cinnarizine induced parkinsonism (FCIP) is one of the most frequent forms and is commonly found in elderly female patients manifesting symmetrical motor symptoms with resting and/or postural tremor, often associated with depression, and occasionally acathisia and dyskinesia ?

FCIP was first described in Brazil in 1984 by De Melo-Souza during the IX Brazilian Congress of Neurology ${ }^{2}$. In his study, De Melo-Souza reported 5 female elderly patients with a past history of flunarizine use presenting with both PK and depression. A few years later, in 1989, De Melo-Souza and Ragazzo presented a larger series at the Annual Meeting of the American Academy of Neurology. In that series, all of the 28 patients ( $25 \mathrm{fe}$ male, with a mean age of 66 years) had used flunarizine $10 \mathrm{mg}$ daily for a mean time of 6 months. Along with a rigid-akinetic syndrome, $60 \%$ of the patients had tremor and $85 \%$ had depression. Only one patient presented with bucolingual dyskinesia and six had akathisia?.

According to Negrotti and Calzetti ${ }^{3}$ and Marti-Masso and Poza ${ }^{4}$ the clinical characteristics of cases with FCIP include: 1) Previous flunarizine or cinnarizine treatment; 2) PK diagnosed after onset of therapy with the drugs; 3) Clinical features are indistinguishable from Parkinson's disease, with a rigidity-akinetic syndrome, resting and postural tremor, but usually with bilateral onset, progressing with symmetrical findings and associated depressive disorder; 4) Predominantly affects elderly female patients; 5) Remission of PK symptoms after drug discontinuation; 6) Other causes of PK (including other drugs) excluded. Curiously, the first cases presented by De Melo-Souza 25 years ago with the main clinical features of FCIP were reported by him as "the crying older little women"1,2,5.
Twenty-five years later, FCIP is widely recognized as one of the most common cause of PK and it is now being called as De Melo e Souza's syndrome $e^{1,5}$.

\section{REFERENCES}

1. Teive HAG, Troiano AR, Germiniani FMB, Werneck LC. Flunarizine and cinnarizine-induced parkinsonism: a historical and clinical analysis. Parkinsonism Relat Disord 2004;10:243:245.

2. Melo-Souza SE. Flunarizina, parkinsonismo e depressão. XI Congresso Brasileiro de Neurologia (Resumos). Goiânia, Brasil, 1984.

3. Negrotti A, Calzetti S. A Long-term follow-up study of Cinnarizine-and Flunarizine-induced Parkinsonism. Mov Disord 1997;12:107-110.

4. Martí-Massó J, Poza JJ. Cinnarizine-Induced Parkinsonism: ten years later. Mov Disord 1998;13:453-456.

5. Maranhão-Filho P. A síndrome de Melo-Souza (1984). Sebastião Eurico de Melo-Souza. In: Maranhão-Filho P. Autores brasileiros: mais de um século de sinais, síndromes e outras contribuições neurológicas e neurocirúrgicas (1878-1998). São Paulo: Editora Omnifarma Ltda, 2008.

Hélio A. G. Teive*

Renato Puppi Munhoz*

Henrique B. Ferraz**

*Movement Disorders Unit/Neurology Service, Internal Medicine Department, Hospital de Clínicas da Universidade Federal do Paraná, Paraná PR, Brazil. E-mail: hagteive@mps.com.br; **Movement Disorders Unit/Neurology and Neurosurgery Department, Universidade Federal de São Paulo, São Paulo SP, Brazil. 